\title{
Feeding and prey capture cycles in the aposymbiontic gorgonian Paramuricea clavata
}

\author{
Rafel Coma ${ }^{1,2}$, Josep-Maria Gili ${ }^{1}$, Mikel Zabala ${ }^{2}$, Tecla Riera ${ }^{2}$ \\ ${ }^{1}$ Institut de Ciències del Mar (CSIC), Passeig Joan de Borbó s/n, E-08039 Barcelona, Spain \\ ${ }^{2}$ Department d'Ecología, Universitat de Barcelona, Avda Diagonal 645, E-08028 Barcelona, Spain
}

\begin{abstract}
A study of the stomach contents of a population of the Mediterranean gorgonian Paramuricea clavata (Risso, 1826) showed that zooplankton accounted for an important share of the diet. Nauplii, copepod eggs, other invertebrate eggs, and other small (100 to $200 \mu \mathrm{m})$ prey items of low motility accounted for $78 \%$ of prey items, though adult calanoid copepods (600 to $700 \mu \mathrm{m}$ ) were also captured. The mean number of prey items per polyp ranged from 1.2 to 3.3 . The prey capture rate was highly dependent upon the density and frequency of occurrence of planktonic prey in the habitat. Peak prey capture levels were recorded in spring and at the end of autumn, while prey capture rates fell off substantially in summer, when the proportion of colonies with contracted polyps was very high. There were significant differences in the prey capture rates between colonies, which was attributed to differences in the spatial distribution of the zooplankton. There were also large differences in prey capture rates within the same colony. Polyps located on the apical and peripheral branches captured twice as many prey as those located in the centre or at the base of the colony. It was estimated that the population, located off the Medes lslands (northwestern Mediterranean) at between 17 and $29 \mathrm{~m}$ depth with a mean density of 32 gorgonians $\mathrm{m}^{-2}$, may capture between $1.52 \times 10^{5}$ and $1.06 \times 10^{6}$ prey items $\mathrm{m}^{-2}$ $\mathrm{d}^{-1}$, according to the time of year. The prey capture rates recorded during a diel cycle, when extrapolated to an annual cycle, suggest that gorgonians play an important role in littoral food webs and particularly in the flow of energy from the plankton to the benthos.
\end{abstract}

KEY WORDS: Gorgonians · Feeding behaviour Prey capture Trophic ecology - Benthic communities . Mediterranean

\section{INTRODUCTION}

Gorgonians are common organisms in sublittoral benthic communities in the Mediterranean Sea (Weinberg 1979, 1980, Gili et al. 1989). In some habitats gorgonians form dense aggregations, with species like Paramuricea clavata contributing more than $40 \%$ of the biomass of the community as a whole (True 1970 , Gili \& Ros 1985). Studies of Mediterranean gorgonians indicate that the distribution ranges and abundance of these organisms depend upon such environmental factors as light, temperature, current direction and flow rates (Riedl 1966, Weinberg 1979, Russo 1985). Considerable work has been carried out on the distribution and abundance patterns of gorgonians and the factors regulating such patterns in tropical seas. The same environmental factors reported for Mediterranean species exert a strong influence on the distribution of trop- ical species (e.g. Kinzie 1970, 1973, Opresko 1973, Grigg 1977, Muzik 1982, Lasker et al. 1983, Yoshioka \& Yoshioka 1989). Recently, Gili \& Ballesteros (1991) postulated that current flow, as a food transport mechanism, and specifically variability in food distribution near the bottom, is the main factor regulating the distribution and abundance of suspension feeders such as gorgonians in sublittoral communities in the Mediterranean. Nevertheless, despite the studies carried out to date, little is known about the food requirements of gorgonians. Description and quantification of the diets of these organisms are essential if we are to be able to characterize the ecological niche and role of gorgonians in littoral benthic communities in the Mediterranean Sea.

Gorgonians are suspension feeders that ingest particulate matter (Lasker 1981a), though it is not yet clear whether the particulate matter is capable of satisfying 
their energy needs. In addition, it has been shown that gorgonians are able to ingest and assimilate dissolved organic matter and mucus and that in certain cases the mucus ingested may satisfy their requirements (Coffroth 1984). In contrast, the capture of zooplanktonic prey by gorgonians has only been documented in a few studies (Leversee 1976, Lasker 1981a). Furthermore, researchers have postulated that the ability of gorgonians to capture vagile prey is low, based on the low densities of nematocysts on the tentacles (Mariscal \& Bigger 1977, Lasker 1981a, Coffroth 1984).

Many anthozoans, such as corals (Porter 1974, Lasker 1979), zoantharians (Sebens 1977), alcyonaceans (Sebens \& Koehl 1984), and actinians (Purcell 1977. Sebens 1981), have been observed to capture zooplankton. However, prey capture rates have seldom been quantified (Porter 1974, Sebens 1977, Lasker 1979). In tropical regions, where zooplankton abundance is lower than in temperate regions, gorgonians may exploit other energy sources (such as symbioses with algae). However, nitrogen, phosphorus, and other nutrients still have to be provided by zooplanktonic prey (Muscatine \& Porter 1977). In any event, gorgonians, which are quantitatively important in certain benthic communities, may furnish a good example of the role of suspension feeders in littoral food chains and in the relationship between the plankton and the benthos in temperate seas.

Paramuricea clavata (Risso, 1826) is a large, strictly Mediterranean, aposymbiontic gorgonian with a highly specific distribution: isolated populations off promontories on capes or islands at depths between 5 and $110 \mathrm{~m}$ (Weinberg 1991) in areas washed by strong currents, or on walls or bottoms with abrupt vertical features that ensure active replenishment of water masses. The object of the present study was to assess the contribution of zooplankton to the diet of $P$. clavata and quantify ingestion rates in preparation for a future assessment of the metabolic budget. Patterns of variation in the diet over an annual cycle and a diel cycle were considered. Furthermore, an attempt was made to relate the prey capture rate to the frequency of occurrence of prey in the habitat and to observe (1) differences in the prey capture rate between colonies within the population and between polyps within the same colony. (2) selectivity, and (3) the impact of the study population on plankton in the study area.

\section{MATERIALS AND METHODS}

The Paramuricea clavata population studied was located on the northern face of the Carall Bernat rock in the Medes Islands (northwestern Mediterranean). Population density was 32 colonies $\mathrm{m}^{-2}$, and the popu- lation considered was located near the upper limit of the species' depth range. Colonies in the population ranged in size from 1 to $55 \mathrm{~cm}$ in height. Samples spanned the entire local depth range between 17 and $29 \mathrm{~m}$. The samples, apical fragments or whole colonies, were immediately fixed in $10 \%$ formaldehyde in sea water.

Annual and diel variations in the diet. To study annual variations, Paramuricea clavata colonies were sampled monthly from July 1990 to May 1991 and biweekly in June and July 1991. Each sample consisted of 1 apical fragment collected from each of 20 different colonies. All samples were collected at 10:00 h to preclude possible circadian influences on the annual pattern of prey capture. The diel pattern was studied over a $24 \mathrm{~h}$ period in April 1992, during which an apical fragment was collected from each of 10 colonies at $4 \mathrm{~h}$ intervals. The statistical significance of the differences in annual and diel variations in the rate of prey capture was tested using an analysis of variance (ANOVA) followed by Scheffé's contrast test (Zar 1984).

Stomach contents and prey biomass. Five polyps from each fragment were dissected under a binocular dissecting microscope and the stomach contents examined. Prey items were identified to the level of the major taxonomic groupings (see Tables $4 \& 5$ ). The length and maximum diameter of all prey items were measured. Prey item biomass was calculated by estjmating the wet weight based on the volume of the geometrical shape that most closely approximated prey item shape (Sebens \& Koehl 1984) and a specific weight of $1.025 \mathrm{~g} \mathrm{~cm}^{-3}$ (Hall et al. 1970). The dry weight was taken to be $13 \%$ of wet weight (Beers 1966. Murphy 1971). Dry weight was converted to organic carbon weight using the generally accepted ratio for zooplankton, $C: D W=0.5$ (Jørgensen et al. 1979)

Inter-polyp variability and sample size. To determine variations in the number of prey items per polyp within the population, a total of 250 polyps were randomly selected from 20 (randomly collected) colonies. The experiment was carried out in spring and repeated in summer 1991. The values recorded were recombined into sample groups of increasing size of 10,20 , $30,40,50,75,100,200$ and 250 polyps. The curve for the quotient of the variance and mean number of prey items per polyp vs sample size was plotted. The experiment provided information on variability in prey capture within the population and on the minimum representative sample size that should be used in studying the stomach contents.

Within-colony variation. The different parts of each colony were arranged in order according to the method of Horton (1945) for classifying effluents in a drainage basin. This method was later modified by Strahler (1952) and applied to gorgonians by Brazeau 
\& Lasker (1988) and by Mitchell et al. (1993). Terminal branches were defined as first-order branches. Higherorder branches were formed by the union of 2 branches of the same lower order. One-factor ANOVA followed by Scheffé's contrast test (Zar 1984) was applied to examine patterns in the relationship between prey capture rate and branch order For this study, 6 colonies were collected and fixed immediately in $10 \%$ formaldehyde in sea water Three replicates of 10 polyps from each branch order of each sample colony were examined.

Zooplankton density. Two zooplankton samples were collected (biweekly) concurrently with the collection of fragments of Paramuricea clavata colonies for the study of annual and diel variations. Plankton nets $22 \mathrm{~cm}$ in diameter with a mesh size of $60 \mu \mathrm{m}$ were employed. The nets were towed over a distance of $40 \mathrm{~m}$ by a diver a short distance $(30$ to $50 \mathrm{~cm}$ ) from the gorgonians. The plankton samples were fixed in $5 \%$ formaldehyde in sea water and identified to the level of the main taxonomic groupings (see Tables $2 \& 3$ ).

Prey-plankton relationship. Selectivity indices were calculated for those zooplankton groups that accounted for more than $5 \%$ of the total of prey items, comparing density (ind. $\mathrm{m}^{-3}$ ) in the plankton and frequency of occurrence as prey in the contents of 100 polyps from each sample. The chi-squared test was applied to the selectivity values as described by Pearre (1982).

Activity rhythms. To study activity rhythms, the expansion state of the polyps of 100 colonies were recorded along each of 50 transects over the annual sampling period and over two $24 \mathrm{~h}$ periods (April, coinciding with polyp sampling, and August). Only the 2 extreme states, expanded or contracted, were considered; no distinctions were made either for intermediate expansion states or for the number of expanded polyps in partially expanded colonies.

Digestion time. On 19 April 1992 an experiment to estimate the digestion time was performed. One apical fragment was collected from each of 90 colonies and placed in filtered sea water at ambient water temperature $\left(14^{\circ} \mathrm{C}\right)$. Ten fragments were fixed in $10 \%$ formaldehyde in sea water immediately. A further 10 fragments were fixed after 30,60, 90, 120, 150, 180, 210 , and $240 \mathrm{~min}$. The stomach contents of 5 polyps on each fragment were examined. The percentage of polyps that were full and the number of prey items per polyp were recorded for each 50 polyp sample.

Prey capture rates. Prey capture rates expressed as number of prey items captured per Paramuricea clavata polyp per day were calculated using the equation:

$$
N=\sum_{t=0}^{D} C-[(C \times t) / D] \text { or } C=N\left[\sum_{t=0}^{D}(1-t / D)\right]^{-1}
$$

where $C=$ number of prey captured polyp-1 $\mathrm{h}^{-1} ; t=$ time (in h); $N=$ prey items per polyp; and $D=$ digestion time (in h). This formula calculates the number of prey captured sample ${ }^{-1} \mathrm{~h}^{-1}$

Effects of predation on the plankton. The total number of prey captured per year were calculated from the daily prey capture rates recorded each month. Since the ambient plankton sample series was more complete (bi-weekly) and since there was good correlation (see Fig. 3) between plankton density and the number of prey items captured by this gorgonian, prey capture values were estimated from the monthly stomach content analyses as well as by extrapolation based on the bi-weekly plankton density values. The estimated prey biomass captured yearly by this Paramuricea clavata population off the Medes Islands was calculated taking into account the results for colony density, polyps, and demographic structure obtained from a study of the growth and production of the population (Coma 1994). variations in prey capture rates based on the rank of the branch on which each polyp was located, and the weight of each type of prey item.

\section{RESULTS}

\section{Variability in prey capture rates vs sample size and between polyps, branches, and colonies}

Fig. 1 depicts the trend in the variance divided by the mean number of prey items per polyp on sample size. The curve flattens out from a sample size of 30 polyps (50 in June), and the variance was less than $5 \%$ of the mean for the first 50 polyps examined. ANOVA revealed that there were no significant differences in the estimates of mean number of prey items per polyp for samples of 50,100, 150, and 200 polyps (March: $p<0.581$; June: $p<0.985$ ). These results make it possible to state with confidence that the sample sizes used in this study were fully representative for the population as a whole.

Significant differences in the mean number of prey items per polyp were observed between colonies (Table 1). There were also significant differences in the percentage of full polyps and the number of prey items captured per polyp for the different-order polyps on the same colony (Fig. 2). The number of prey items decreased as the branch order increased. These differences were significant between first-order branches and the rest of branches (ANOVA, $p<0.001$; Scheffe's test). A colony's peripheral (primary) branches captured around $50 \%$ more prey than did the polyps located on the higher-order branches. The number of prey items in the polyps also tended to decrease with the progression from second-to third- to fourth-order branches, but the differences were not significant. 


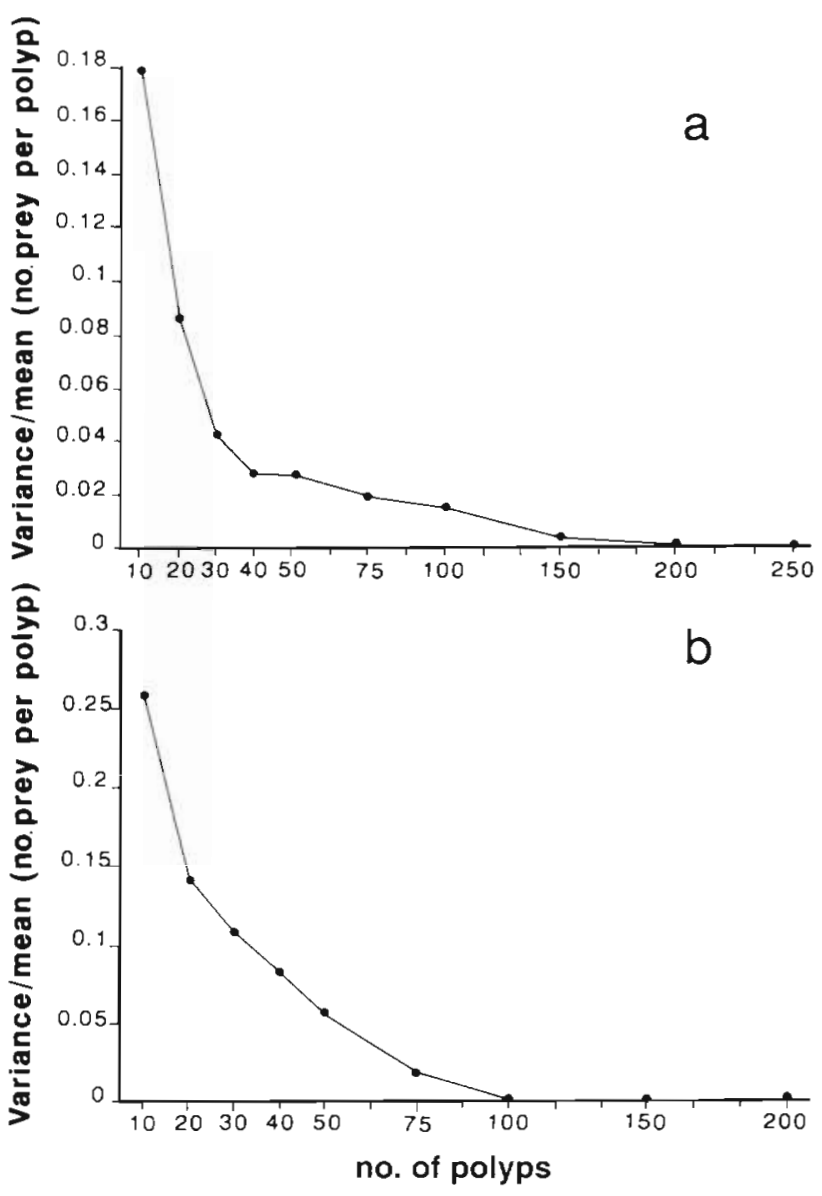

Fig. 1. Paramuricea clavata. Curve of the quotient (variance)/ (mean number of prey items per polyp) vs sample size, used to determine the minimum representative sample size of polyps: (a) March; (b) June

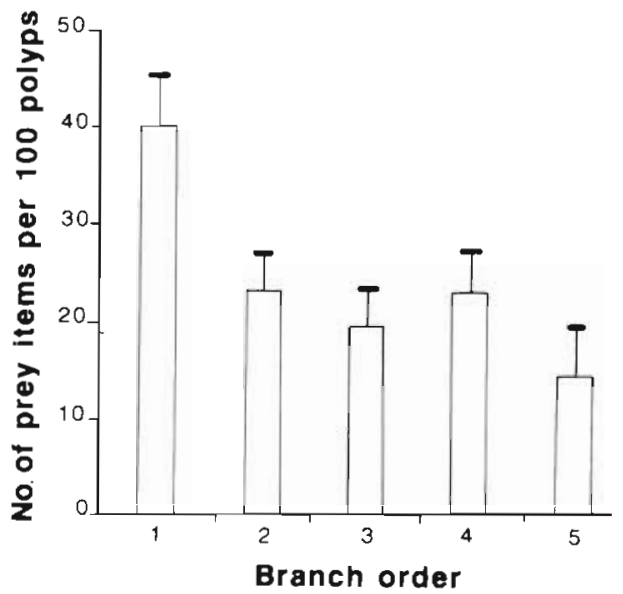

Fig. 2. Paramuncea clavata. Number of prey items captured by 100 polyps according to polyp position (branch order) on the colony (error bars depict 1 standard error)
Table 1 paramuricea clavata. Summary of 1 -factor ANOVA followed by Scheffés test applied to examine patterns in the relationship between prey capture rate, branch order and sex. ns: not significant

\begin{tabular}{|lccc|}
\hline Variables tested & $F$ & df & Sig. \\
\hline Colony vs prey & 4.025 & 761 & 0.0013 \\
All branch orders vs prey & 2.041 & 761 & $\mathrm{~ns}$ \\
Branch orders 1 vs prey & 7.509 & 761 & 0.0062 \\
Branch orders 1 and 2 vs prey & 2.39 & 359 & $\mathrm{~ns}$ \\
Branch orders 2 and 3 vs prey & 0.216 & 359 & $\mathrm{~ns}$ \\
Branch orders 3 and 4 vs prey & 0.294 & 359 & $\mathrm{~ns}$ \\
Branch orders 4 vs prey & 0.722 & 221 & $\mathrm{~ns}$ \\
Branch orders 1 and 3 vs prey & 8.541 & 359 & 0.0037 \\
Branch orders 1 and 4 vs prey & 5.403 & 359 & 0.0206 \\
Branch orders 1 and 5 vs prey & 4.409 & 221 & 0.0369 \\
Sex vs prey & 12.133 & 761 & 0.0005 \\
& & & \\
\hline
\end{tabular}

\section{Plankton dynamics}

The plankton was classified into 3 categories on the basis of abundance in the samples over the annual period: (1) Items that were present in all samples and contributed quantitatively important shares, such as copepods (55\% of the total), nauplii (15\%), and eggs $(15 \%)$; these 3 items predominated in the plankton over the annual cycle and together accounted for $85 \%$ $( \pm 5 \%)$, on average, of the plankton catches over the year. (2) Groups that were not always present but were quantitatively important at certain times of the year, such as appendicularians (13\% in May), siphonophores (10\% in May), and lamellibranch larvae $10 \%$ in February). (3) The remaining items whose quantitative contributions were in all cases less than $1 \%$ (Table 2). Three periods of peak density were observed, one in autumn, another at the beginning of winter and the third in spring (Fig. 3).

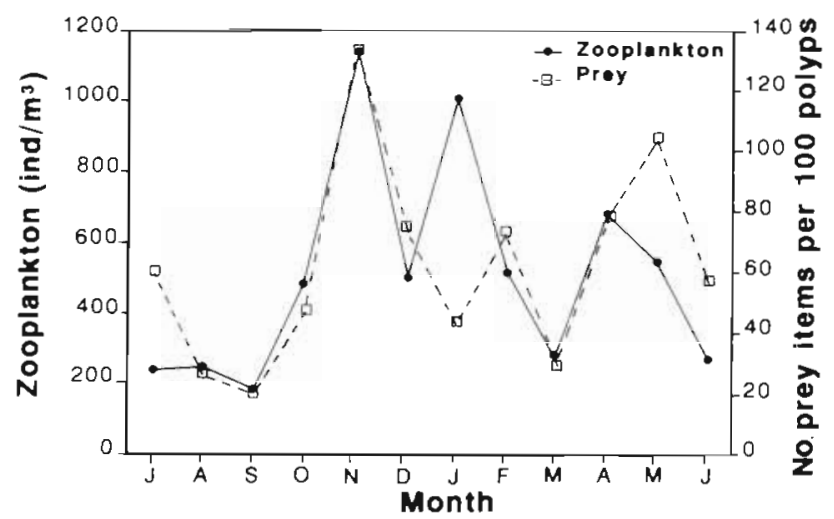

Fig. 3. Paramuricea clavata. Comparison of trends in total number of prey items and epibenthic zooplankton density values for all samples over the annual sampling period (1990 to 1991) 
There was no clear pattern of variation in total plankton density over the night-day cycle (Table 3 ). The mean density was $1428 \pm 148$ ind $\mathrm{m}^{-3}$, ranging from a minimum of 1154 ind. $\mathrm{m}^{-3}$ at $14: 00 \mathrm{~h}$ to a maximum of 1534 ind. $\mathrm{m}^{-3}$ at 22:00 h. Copepodids and copepod eggs and nauplii were the most abundant planktonic organisms. The 2 lowest densities of invertebrate larvae occurred in the early morning, whereas dinoflagellates and appendicularian densities increased after sunrise.

\section{Annual variation in the diet}

The prey capture rate was subject to marked seasonal variations (Fig. 3). The highest numbers of prey items per polyp were recorded in May and November. The percentage of full polyps was also highest in these months (Table 4 ), and the 2 parameters were positively correlated $(\mathrm{r}=0.949, \mathrm{p}<0.001)$, such that there were 2 peaks in prey capture, one in spring and the other in autumn, and the peak values were significantly different from the mean (ANOVA, $p<0.001$; Scheffé's test). The summer minimum was also significant (ANOVA, $\mathrm{p}<0.001$; Scheffé's test).

\section{Stomach contents: nature, number, and size of prey}

Most of the prey items observed inside the gastrovascular cavity of Paramuricea clavata were zooplankton (Tables $4 \& 5$ ). The most abundant were nauplii, copepod eggs, and invertebrate eggs and larvae, all characterized by small size (100 to $200 \mu \mathrm{m})$ and low motility. These 3 groups accounted for $78 \%$ of all the prey items captured over the annual sampling period (Table 4). A highly diverse spectrum of other zooplankton were also found in the samples but these were not quantitatively important. Maximum prey length was mainly between 100 and $800 \mu \mathrm{m}$, with prey between 100 and $200 \mu \mathrm{m}$ being most abundant $(84.3 \%)$. The mean number of prey items per full polyp ranged from 1.2 to 3.3 , though on rare (8 of 1602) occasions polyps containing from 10 to 87 prey items were observed. These extreme outlying values have been omitted from Table 4 on account of their high deviation from the mean. In all, $90 \%$ of the polyps contained between $1(62 \%)$ and 3 prey items.

\section{Dietary selectivity}

The range of prey types observed in the diet of Paramuricea clavata was lower than the range in the ambient plankton. Throughout the annual sampling

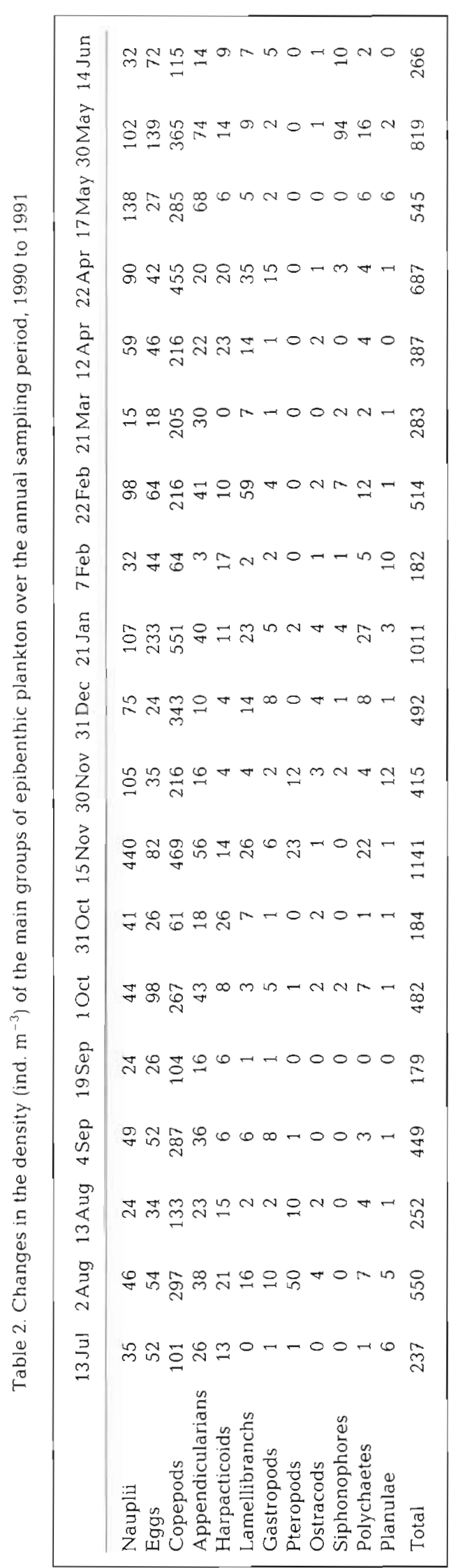


Table 3. Changes in the density (ind. $\mathrm{m}^{-3}$ ) for the main groups of epibenthic plankton over the diel sampling period, 19 and 20 April 1992

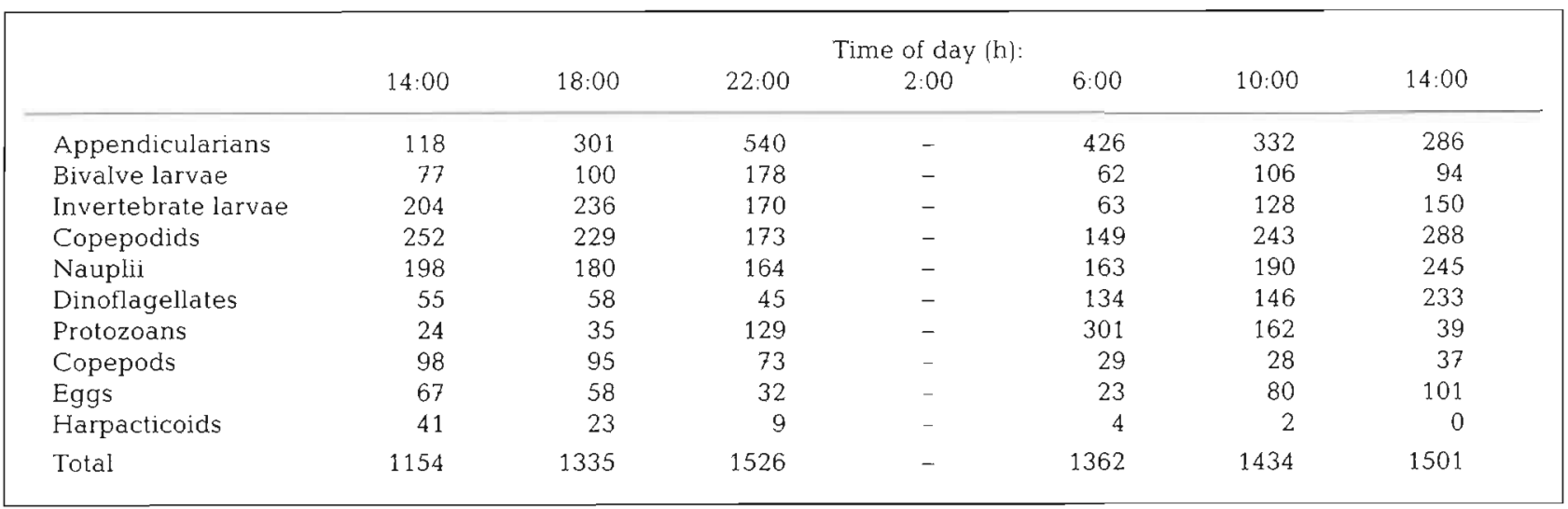

period there was a dietary preference towards groups of low motility that were highly abundant in the plankton at the time, such as copepod eggs and nauplii and other benthic invertebrate eggs and larvae. The highest positive selectivity was recorded for copepod eggs, for which values were significant over most of the year (Table 6). There was also significant positive selectivity towards other groups, such as bivalve larvae and planulae during their periods of peak abundance in the plankton. The trend for nauplii was similar, whereas there appeared to be a significant negative selectivity towards copepods throughout the year.

The number of prey items captured by Paramuricea clavata was closely related to prey availability in the plankton (Fig. 3). A single occasion excepted, an increased higher zooplankton density was reflected by an increase in the total number of prey items captured. The percentage of polyps containing prey items was correlated with ambient plankton density $(r=0.671$, $p<0.02$ ). A similar correlation was observed between plankton density and the mean number of prey items per polyp $(r=0.645, p<0.05)$

\section{Diel variation in the diet}

Prey capture rates, expressed as the percentage of full polyps and the number of prey items per polyp, were fairly constant over the diel cycle. Most of the prey were copepod nauplii or eggs or harpacticoid copepods (Table 5). Below, times at which capture rates were not significantly different are underlined:

$$
\begin{array}{llllll}
14: 00 & 18: 00 & 22: 00 \quad 2: 00 \quad 6: 00 & 10: 00 \quad 14: 00
\end{array}
$$

A significant increase in prey capture was observed at 10:00 h, coinciding with higher capture levels of copepod nauplii and eggs.
Nearly all the Paramuricea clavata colonies showed all polyps expanded throughout the entire diel cycle. The lowest percentage of colonies with expanded polyps was observed at 14:00 h (80\%; Table 5).

Selectivity values for copepod eggs and copepod nauplii were significant during the diel cycle (Table 7 ). A positive selectivity for benthic harpacticoid copepods was also observed.

\section{Activity rhythms}

Synchrony in the expansion or contraction of all the polyps on the colonies was high, such that the most likely states were 'all open' or 'all closed'. There was no circadian cycle of expansion and contraction. The colonies remained expanded over the entire $24 \mathrm{~h}$ diel sampling period in spring, whereas they were all con-

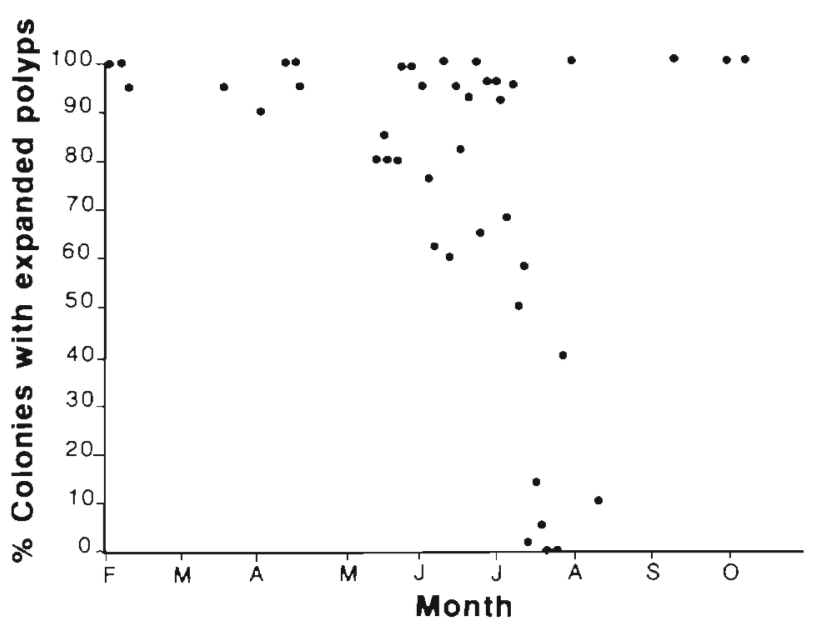

Fig. 4. Paramuricea clavata. Percentage of expanded colonies over part of the annual sampling period 
tracted over the entire $24 \mathrm{~h}$ diel sampling period in summer. The percentage of colonies with expanded polyps was much lower in summer than during the rest of the year (Fig. 4), coinciding with the period of lowest ambient plankton density and number of prey captured. The summer decline in feeding activity by the Paramuricea clavata colonies also coincided with the period of thermal stratification of the water column and with the period of lowest hydrodynamic activity in the study area (Pascual \& Flos 1984).

\section{Prey digestion time}

Stomachs contained identifiable prey up to $3 \mathrm{~h}$ after capture, but none or only a very few after $4 \mathrm{~h}$. Due to low numbers of prey observed during the experiments concerning prey digestion time, data are not tabulated. The results, however, suggested that prey items present in the stomach contents had been captured in the last 0 to $3 \mathrm{~h}$, with a few somewhat older fragments. Although digestion time is dependent upon temperature (Purcell 1992) and the experiment was carried out in the cold season $\left(14^{\circ} \mathrm{C}_{i}\right.$ temperature range: 12 to $21^{\circ} \mathrm{C}$ ), for subsequent calculations a conservative mean digestion time of $4 \mathrm{~h}$ was assumed, in concordance with the times reported for other species of gorgonians (Coffroth 1984) and anthozoans (Boschma 1925, Yonge \& Nicholls 1930, Sebens \& Koehl 1984, Sebens 1987).

\section{Prey capture rates}

Table 8 summarizes the daily prey capture values as well as the total number of prey captured by the population over the entire year. The calculation took into account changes in the factors affecting prey capture rates: month of the year (prey availability), time of day, polyp position on the colony, and digestion time. Because both polyp density and number of prey captured per polyp change with branch order, to calculate total consumption we estimated the

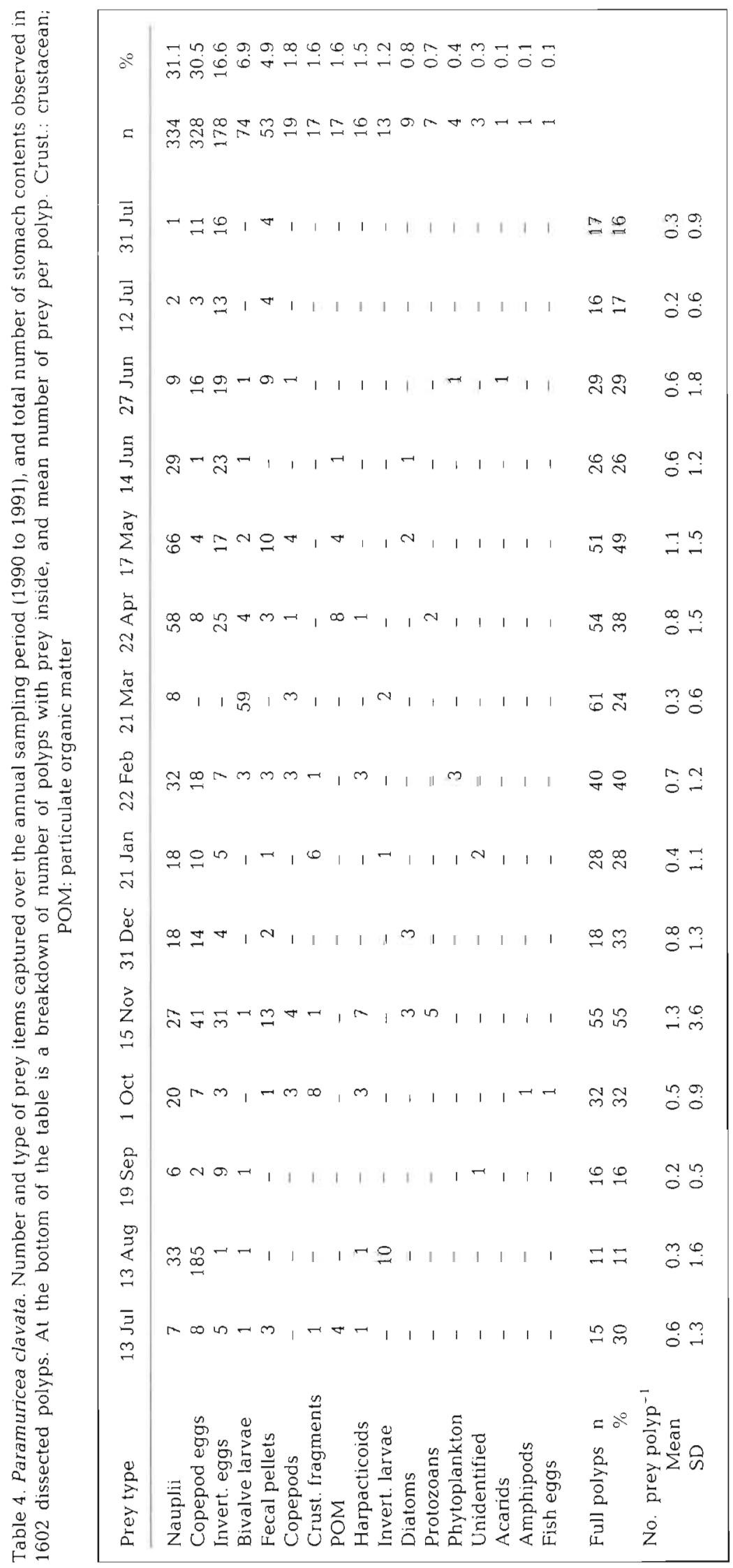


Table 5. Paramuricea clavata. Number and type of prey items captured over the diel sampling period (19 to 20 April 1992) (50 polyps examined per sample), and total number of stomach contents observed in 350 dissected polyps. At the bottom of the table is a breakdown of number of polyps with prey inside, and mean number of prey per polyp

\begin{tabular}{|c|c|c|c|c|c|c|c|c|c|}
\hline \multirow[t]{2}{*}{ Prey type } & \multicolumn{7}{|c|}{ Time of day $(h)$ : } & \multirow[t]{2}{*}{$\mathrm{n}$} & \multirow[t]{2}{*}{$\%$} \\
\hline & $14: 00$ & $18: 00$ & $22: 00$ & $2: 00$ & $6: 00$ & $10: 00$ & $14: 00$ & & \\
\hline Bivalve larvae & - & - & 1 & 1 & 3 & - & - & 5 & 4 \\
\hline Nauplii & 5 & 8 & 6 & 6 & 8 & 30 & 7 & 70 & 56 \\
\hline Protozoans & - & - & - & 2 & - & - & 2 & 4 & 3.2 \\
\hline Copepods & - & - & - & 1 & - & - & - & 1 & 0.8 \\
\hline Copepod eggs & 5 & - & 5 & 1 & 5 & 10 & 2 & 28 & 22.4 \\
\hline Harpacticoids & 5 & 2 & 3 & 2 & - & 4 & 1 & 17 & 13.6 \\
\hline \multirow{2}{*}{ Full polyps $\mathrm{n}$} & 9 & 9 & 11 & 10 & 10 & 28 & 9 & & \\
\hline & 18 & 18 & 22 & 20 & 20 & 56 & 18 & & \\
\hline \multicolumn{10}{|l|}{ No. prey polyp -1} \\
\hline Mean & 0.3 & 0.2 & 0.3 & 0.3 & 0.3 & 0.9 & 0.2 & & \\
\hline $\mathrm{SD}$ & 0.8 & 0.5 & 0.7 & 0.6 & 0.7 & 1.1 & 0.5 & & \\
\hline
\end{tabular}

Table 6. Paramuricea clavata. Selectivity index (Pearse 1982) values for prey items contributing more than $5 \%$ to both the plankton and the diet over the annual sampling period (1990 to 1991) and percentage of samples in which selectivity index values were significantly positive or negative

\begin{tabular}{|c|c|c|c|c|c|c|c|c|c|c|c|c|c|c|}
\hline & 13 Jul & 13 Aug & $19 \mathrm{Sep}$ & $1 \mathrm{Oct}$ & 15 Nov & $31 \mathrm{Dec}$ & $21 \mathrm{Jan}$ & $22 \mathrm{Feb}$ & $21 \mathrm{Mar}$ & $22 \mathrm{Apr}$ & 17 May & $14 \mathrm{Jun}$ & Pos. & $\mathrm{Neg}$ \\
\hline Nauplii & ns & ns & ns & 0.001 & -0.001 & 0.001 & 0.001 & 0.001 & ns & 0.001 & 0.001 & 0.001 & 60 & 8 \\
\hline Eggs & 0.02 & 0.001 & 0.001 & ns & 0.001 & 0.001 & ns & 0.001 & ns & 0.001 & 0.001 & 0.05 & 75 & - \\
\hline Bivalve larvae & ns & ns & ns & - & ns & - & - & ns & 0.001 & ns & ns & ns & 8 & - \\
\hline Invert larvae & - & 0.01 & - & - & - & - & ns & - & ns & - & - & - & 8 & - \\
\hline Harpacticoids & ns & ns & - & ns & 0.001 & - & - & ns & - & ns & - & - & 8 & - \\
\hline Copepods & -0.001 & -0.001 & - & ns & -0.001 & - & - & -0.001 & -0.001 & -0.001 & -0.001 & - & - & 60 \\
\hline
\end{tabular}

Table 7. Paramuricea clavata. Selectivity index (Pearse 1982) values for prey items contributing more than $5 \%$ to both the plankton and the diet over the diel sampling period (19 to 20 April 1992) and percentage of samples in which selectivity index values were significantly positive or negative

\begin{tabular}{|c|c|c|c|c|c|c|c|c|}
\hline & $14: 00$ & $18: 00$ & $22: 00$ & $\begin{array}{c}\text { Time of day }(\mathrm{h}) \text { : } \\
6: 00\end{array}$ & $10: 00$ & $14: 00$ & Pos. & Neg. \\
\hline Nauplii & ns & 0.001 & 0.005 & 0.001 & 0.001 & 0.001 & 83 & - \\
\hline Copepod eggs & 0.001 & - & 0.001 & 0.001 & 0.001 & ns & 67 & - \\
\hline Harpacticoids & 0.001 & 0.005 & 0.001 & - & 0.001 & 0.001 & 83 & - \\
\hline Bivalve larvae & - & - & ns & 0.05 & - & - & 17 & - \\
\hline
\end{tabular}

proportion of polyps on different-order branches (Table 8 ). The mean number of prey captured $\mathrm{m}^{-2} \mathrm{~d}^{-1}$ was between 215386 and 469932 , with minimum values in summer and maximum values in spring and autumn. Overall, the annual number of prey captured can be put at between 75 and $165 \times 10^{6}$ prey m $^{-2} \mathrm{yr}^{-1}$. Table 9 sets out the conversion of number of prey to biomass for each prey type along with an estimate of prey biomass captured, equivalent to between 6 and $13 \mathrm{~g} \mathrm{C} \mathrm{m}^{-2} \mathrm{yr}^{-1}$.

\section{DISCUSSION}

Diet

Feeding is one of the least understood aspects of gorgonian biology, possibly because significant quantities of identifiable prey items have been difficult to find in stomach samples (Lasker 1981a). Moreover, the capture of zooplanktonic prey items has only been reported sporadically and always in laboratory experi- 
ments: Leversee (1976) observed the prey capture process using $A_{r}$ temia nauplii in experiments on feeding by Leptogorgia. In his experiments on feeding by 3 tropical gorgonian species, Lasker (1981a) employed Artemia cysts, which are similar to copepod eggs in size and buoyancy. However, Lasker et al. (1983) were unable to detect significant quantities of zooplanktonic prey in the stomachs of these and other gorgonians. In addition, Sponaugle \& LaBarbera (1991) and Dai \& Lin (1993) studied the prey capture process in different gorgonian species, but always used simplified diets.

The presence of zooplanktonic prey in the stomach contents of gorgonians was expected, since despite dietary diversity, corals (Porter 1974, Lasker 1981b) and anemones (Purcell 1977. Sebens 1981) have been observed to capture copepods and other large zooplanktonic prey. Some species of alcyonaceans with polyps very similar in size to the majority of gorgonians (e.g. Alcyonium siderium), mostly capture small (256 to $345 \mu \mathrm{m})$ prey items of low motility, such as foraminiferans and invertebrate larvae (Sebens \& Koehl 1984). However, it appears that even in corals, whose energy needs may be satisfied by metabolites contributed through symbiosis with algae (Johannes et al. 1970), the capture of zooplanktonic prey is necessary for growth (Edmondson 1929, Yonge \& Nicholls 1931. Franzisket 1970, Wellington 1982, Sebens 1987) and as a source of nitrogen, phosphates, and other nutrients that cannot be produced by zooxanthellae (Muscatine \& Porter 1977). Many gorgonians previously studied have zooxanthellae and, therefore, probably require less zooplankton food than Paramuricea clavata. Most earlier studies on the feeding of gorgonians have been carried out in the laboratory using simplified diets ${ }_{i}$ hence the actual resources on which the diets of gor-

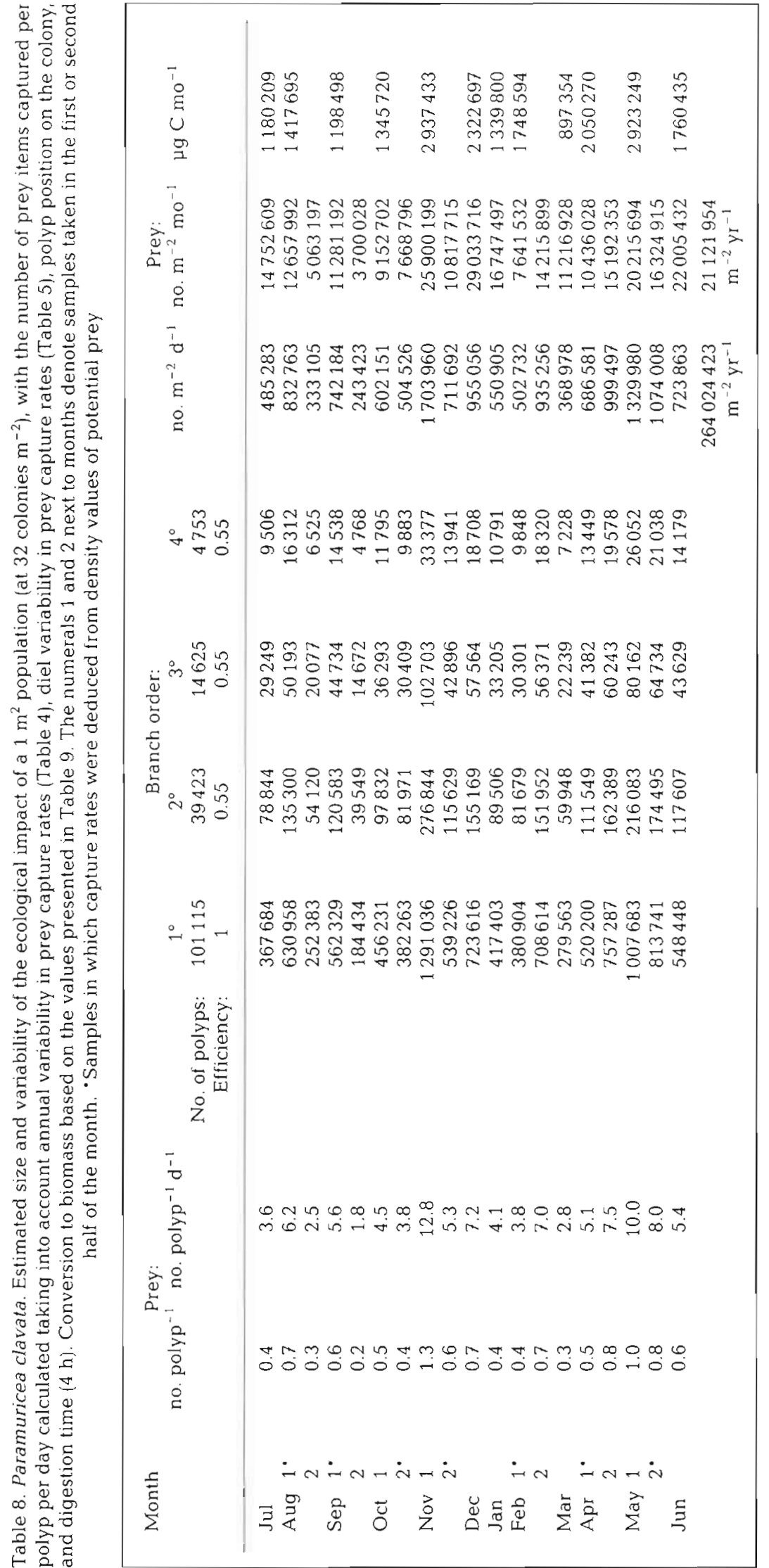


Table 9. Paramuricea clavata. Prey items captured, showing conversion of mean biometric values from $\mu \mathrm{m}$ to volume $\left(\mathrm{mm}^{3} \times 10^{-3}\right)$, fresh weight (FW, $\mu g_{j}$ specific weight $\left.=1.025 \mathrm{~g} \mathrm{~cm}^{-3}\right), \mathrm{dry}$ weight (DW, $\mu \mathrm{g} ; 13 \%$ fresh weight) and weight in organic carbon (C, $\mu$ g; $50 \%$ dry weight). POM: particulate organic matter

\begin{tabular}{|lccccccc}
\hline & $\begin{array}{c}\text { Mean } \\
\text { length }\end{array}$ & $\begin{array}{c}\text { Mean } \\
\text { width }\end{array}$ & $\begin{array}{c}\text { Mean } \\
\text { depth }\end{array}$ & $\begin{array}{c}\text { Mean } \\
\text { volume }\end{array}$ & FW & DW & C \\
\hline Nauplii & 144 & 117 & 55 & 0.48 & 0.49 & 0.06 & 0.03 \\
Copepod eggs & 117 & - & - & 0.85 & 0.87 & 0.11 & 0.06 \\
Invert. eggs & 100 & - & - & 0.53 & 0.54 & 0.07 & 0.04 \\
Bivalve larvae & 243 & 170 & 95 & 2.05 & 2.10 & 0.27 & 0.14 \\
Fecal pellets & 450 & 128 & 128 & 3.85 & 3.95 & 0.51 & 0.26 \\
Copepods & 495 & 200 & 90 & 4.67 & 4.78 & 0.62 & 0.31 \\
Crustacean fragments & 253 & 133 & 45 & 0.79 & 0.81 & 0.11 & 0.05 \\
POM & 105 & - & - & 0.60 & 0.62 & 0.08 & 0.04 \\
Harpacticoids & 389 & 121 & 70 & 1.73 & 1.77 & 0.23 & 0.11 \\
Invert. larvae & 180 & 70 & 70 & 0.46 & 0.47 & 0.06 & 0.03 \\
Diatoms & 133 & - & - & 1.24 & 1.27 & 0.17 & 0.08 \\
Protozoans & 480 & 50 & 50 & 0.63 & 0.64 & 0.08 & 0.04 \\
Algae & 353 & 100 & 50 & 0.93 & 0.95 & 0.12 & 0.06 \\
Unidentified & 247 & 70 & 50 & 0.45 & 0.46 & 0.06 & 0.03 \\
Acarids & 200 & 140 & 75 & 1.10 & 1.13 & 0.15 & 0.07 \\
Amphipods & 560 & 180 & 150 & 7.92 & 8.11 & 1.05 & 0.53 \\
Fish eggs & 1300 & 700 & 300 & 142.94 & 146.52 & 19.05 & 9.52 \\
\hline
\end{tabular}

gonians are based and the degree of variation according to species and latitude are still largely unknown.

Unlike the previously studied gorgonians, Paramuricea clavata regularly feeds on zooplanktonic prey. The prey items captured by $P$. clavata are principally nauplii and eggs - common components in the plankton - that are small in size (100 to $200 \mu \mathrm{m})$ and of low motility. Nevertheless, the diet of this species is quite varied (Table 2), and larger prey items that are relatively powerful swimmers, such as certain adult calanoid copepods, were sometimes observed.

Anthozoans that feed on zooplankton capture their prey with the help of nematocysts, specialized cells located on the tentacles. The absence of zooplankton in the stomach contents of gorgonians has been attributed to the low number of nematocysts arming their tentacles (Mariscal \& Bigger 1977). Nematocysts in Paramuricea clavata are atrichous ( 9 to $10 \mu \mathrm{m}$ ) with a long, poorly armed filament, and nematocyst density was low (no more of 50 nematocysts have been observed in tentacle fragments of $0.5 \mathrm{~mm}$ length) Pinnulate tentacles (Lasker 1981a) and nematocyst type and density may explain the capture of the least motile prey items but cannot account for the easy capture of more motile prey. Although we have no direct evidence, more than 1 polyp may cooperate in capturing larger prey items, since the polyps are spaced closely together. A similar process has been observed in hydroid colonies, in which several polyps may work together to capture large prey items such as nematodes (Christensen 1976).
The absence of zooplankton in the stomach contents of gorgonians has led some workers to propose the existance of alternative food sources, such as suspended amorphous particulate matter (Lasker 1981a). mucus produced by corals (Coffroth 1984), and dissolved organic matter (Murdock 1978). The most popular belief is that gorgonians have a mixed diet based on particulate and dissolved organic matter, including the food supply from symbiosis with zooxanthellae (Farrant et al. 1987). The occasional capture of zooplanktonic prey has been observed in tropical gorgonians (though ingestion of zooplankton was not quantified), but amorphous particles were the primary food source (Lasker 1981a).

Diatoms have been reported in the diets of 2 Alcyonium species (Roushdy \& Hansen 1961, Sebens \& Koehl 1984). The contribution of diatoms to the diet of Paramuricea clavata was minor. Unsuitable polyp size and predation method were probably the reasons why phytoplankton was not exploited as a food resource, and this would appear to be a common trait shared by all coelenterates (Sebens 1987)

Studies on the energetics of zooplankton and other food sources in the diets of gorgonians, like those carried out for other anthozoans (Edmunds \& Davies 1986 , Zamer \& Shick 1987), could assist in clarifying the role of zooplankton in the diets of these organisms. To date no energy balance has been published for gorgonian metabolism. An approximation of the metabolic balance in Paramuricea clavata (Coma 1994) has made it possible to quantify the contribution of zooplankton in the diet of this species. The energy ingested in the 
form of zooplankton met $42.8 \%$ of the requirements for net production and the basal metabolism. This shows that zooplankton comprises a share of the resources making up the diet of $P$. clavata. The dietary strategy of this species is doubtless a type of mixed diet which is also based on particulate matter and dissolved organic matter

\section{Factors regulating prey capture}

The prey capture rate of Paramuricea clavata depends upon the density of plankton in the habitat. Over the annual study period, the periods of peak prey capture coincided with the periods of highest plankton concentration. Only in January was there a discrepancy, with a reduction in prey capture rates in relation to ambient plankton density; however, at that time of year the plankton was composed chiefly of calanoid copepods, which readily escape from the tentacles of the polyps.

Zooplankton densities and prey capture rates remained fairly constant over the diel sampling period, except for the significant peak recorded at 10:00 h. The main factors regulating feeding in passive suspension feeders have been shown to be prey concentration and water flow rate (Leversee 1976, Patterson 1991). Although no flow rate data are available, the significant correlation between plankton density and stomach contents over the annual cycle suggests that the feeding peak observed may have been caused by a substantial change in flow rate.

The fall in the prey capture rate during the summer coincided with a high percentage of contracted colonies in the population. Contraction of polyps by anthozoans has been shown to be associated with a decrease in the metabolic rate (Robbins \& Shick 1980, Lasker 1981b) and to enhance the conservation of energy reserves (Campbell 1974, Sebens \& DeRiemer 1977). The summer contraction period coincided with lower density levels for potential prey items in the plankton (Fig. 3). Contraction lowers the energy budgets of colonies when prey density is low and enables the colonies to survive by decreasing respiratory expenditures to nearly half that in the expanded state (Sebens 1987).

There was high variability in prey capture rates between different colonies within the population. The differences in prey capture have been attributed to patchy distribution of littoral zooplankton in the studied area. This spatial variability also implies temporal variability, and both may appear more distinctly when the scale of sampling is lower than that employed in this experiment and probably also in many other previous experiments. However, the nearly linear relation- ship between the number of prey items captured and ambient plankton density is indicative of a species that is regulated only weakly by internal feeding rhythms but is strongly conditioned by the external availability of prey of the right size and motility. On the other hand, differences in capture rates between differentorder branches could be explained by differential flow rates over and around the colony, which would be greater if it were a bush (when self shading could occur in the middle) rather than a fan.

The most pronounced differences in prey capture rates occurred among the polyps of the same colony. Apical polyps are more effective than the others at capturing prey. Furthermore, investigation of other aspects of the biology of Paramuricea clavata (Coma 1994) revealed evidence of similar differences in growth rate and gonadal biomass. Only higher ingestion rates for apical polyps would be consistent with those results, since the metabolite transport capability of gorgonians appears to be poor (Murdock 1978). Coffroth (1984) noted that the apical branches of the gorgonian Pseudoplexaura porosa had higher mucus capture rates than those of the inner branches, but since polyp density on the apical branches was also higher, it is not clear whether the difference was attributable to higher capture rates per polyp or to a larger surface area for prey capture. Coffroth (1984) suggested that the polyps on the apical branches may be more likely to contact components of the plankton than are those on inner branches. The rate and dynamics of water flow circulating through a gorgonian population have also been reported to alter the likelihood of prey capture by colonies (Leversee 1976). As observed in other benthic suspension feeders, the colonies of a single population interact by affecting the direction and rate of flow reaching neighbouring colonies (Patterson 1984, Okamura 1985, McFadden 1986). Nearby colonies may affect the gravitational deposition of particles and components of the zooplankton (LaBarbera 1984). The breaking effect of neighbouring colonies on water flow would cause the polyps on the peripheral and apical branches to be more favourably positioned to capture prey, and prey capture by those polyps could likewise exert an adverse light shading effect on prey capture by the polyps on the inner branches.

\section{Prey capture rates}

Taking all the foregoing variables into account, we estimated a mean prey capture rate ranging between 1.1 and 8 prey items polyp ${ }^{-1} \mathrm{~d}^{-1}$, equivalent to the ingestion of between 0.09 and $0.64 \mu \mathrm{g} \mathrm{C}$ polyp ${ }^{-1} \mathrm{~d}^{-1}$ Digestion time generally is the weakest link in estimates of prey capture rates. The mean time of $4 \mathrm{~h}$ used 
in this study could vary significantly for a number of reasons. Thus, although the experiment on digestion time was carried out in spring and all the colonies were expanded, the initial number of prey items per 100 polyps was only 30 , just half the expected mean value for that time of year. In addition, water temperature during April $\left(14^{\circ} \mathrm{C}\right)$ was close to the yearly minimum $\left(12^{\circ} \mathrm{C}\right)$, and it has been well established that mean digestion time should decrease as temperature rises (Purcell 1992). Nevertheless, the digestion time recorded was consistent with the digestion times reported for other coelenterates of similar size. The literature values range from $2 \mathrm{~h}$ for hydroids (Barangé \& Gili 1988), 2.5 to $5 \mathrm{~h}$ for scyphomedusae (Purcell 1992), 3 to $4.5 \mathrm{~h}$ for ctenophores (Reeve \& Walter 1978), and 4 to $6 \mathrm{~h}$ for alcyonaceans (Sebens \& Koehl 1984) to between 3 and 14 h for corals (Boschma 1925, Yonge \& Nicholls 1930, Porter 1974). The digestion time observed was also consistent with the small size range of prey that predominates in the diet of Paramuricea clavata and would appear to be closer to the digestive dynamics of hydrozoans than of corals.

\section{Effect of predation on the plankton}

The prey capture rates for the population as a whole and the effect of predation by Paramuricea clavata on plankton populations were very high. Based on the density of the populations of this gorgonian in the study area (32 colonies $\mathrm{m}^{-2}$, i.e. 159916 polyps $\mathrm{m}^{-2}$ and $221 \mathrm{~g}$ dry $\mathrm{wt} \mathrm{m}^{-2}$ ), prey capture rates were estimated at between 152139 and 1064975 prey m${ }^{-2} \mathrm{~d}^{-1}$. the equivalent of removing between 12.2 and $85.2 \mathrm{mg}$ $\mathrm{C} \mathrm{m}^{-2} \mathrm{~d}^{-1}$ from the plankton. Data such as those reported here furnish evidence that gorgonians, like other benthic zooplanktivores, may play a major role in littoral food webs and, in particular, in the flow of energy between the plankton and the benthos. Nevertheless, this contribution should be regarded only as an initial approximation, and in view of the high spatial and temporal variability in prey capture rates, additional efforts to determine the extent and scale of the processes relating to the feeding strategies of gorgonians and other benthic zooplanktivores should be conducted.

Acknowledgements. The authors gratefully acknowledge the helpful assistance of the colleagues who collaborated in the Medes Islands research programme, particularly to Miss Marta Ribes. We also thank Prof. R. N. Hughes, Dr R. G. Hughes, Dr V. Alvà and H. R. Lasker for their critical reviews and comments which helped to improve and clarify the manuscript. Thanks also to Mr R. Sacks for his help in preparing the English version. This work was supported by a CICYT grant, contract number PB91-0906.

\section{LITERATURE CITED}

Barangé, M., Gili, J. M. (1988). Feeding cycles and prey capture in Eudendrium racemosum (Cavolini, 1785). J. exp. mar. Biol. Ecol. 115: 281-293

Beers, J. R. (1966). Studies on the chemical composition of the major zooplankton groups in the Sargasso Sea off Bermuda. Limnol. Oceanogr. 11:520-528

Boschma, H. (1925). On the feeding reactions and digestion in the coral polyp Astrangia danae, with notes on its symbiosis with zooxanthellae. Biol. Bull 49: 407-439

Brazeau, D. A., Lasker, H. R. (1988). Inter- and intraspecific variation in gorgonian colony morphology: quantifying branching patterns in arborescent animals. Coral Reefs 7 $139-143$

Campbell, R. D. (1974). Cnidaria. In: Giese, A. C., Pearse, J. S. (eds.) Reproduction of marine invertebrates I. Acoelomate and pseudocoelomate metazoans. Academic Press, New York, p. 133-199

Christensen, H. (1976). Ecology of Hydractinia echinata. I Feeding biology. Ophelia 4: 245-275

Coffroth, M. A. (1984). Ingestion and incorporation of coral mucus aggregates by a gorgonian soft coral. Mar Ecol Prog. Ser. 17: 193-199

Coma, R. (1994). Evaluación del valance energético de dos especies de cnidarios bentónicos marinos. Ph.D. thesis, University of Barcelona

Dai, C. H., Lin, M. C. (1993). The effects of flow on feeding of three gorgonians from southern Taiwan. J. exp. mar. Biol. Ecol. 173: 57-69

Edmondson, C. H. (1929). Growth of Hawaiian corals. Bull. Bernice P. Bishop Mus. 58: 1-38

Edmunds, P. J., Davies, P. S. (1986). An energy budget for Porites porites (Scleractinia). Mar. Biol. 92: 339-347

Farrant, P. A., Borowitzka, M. A., Hinde, R., King, R. J. (1987). Nutrition of the temperate Australian soft coral Capnella gaboensis II. The role of zooxanthellae and feeding. Mar. Biol. 95: 575-581

Franzisket, L. (1970). The atrophy of hermatypic reef corals maintained in darkness and their subsequent regeneration in light. Int. Rev. ges. Hydrobiol. 55: 1-12

Gili, J. M., Ballesteros, E. (1991). Structure of cnidarian populations in Mediterranean sublittoral benthic communities as a result of adaptation to different environmental conditions. In: Ros, J. D., Prat, N. (eds.) Homage to Ramón Margalef or why there is such pleasure in studying nature. Oecologia aquat. 10: 243-254

Gili, J. M., Murillo, J., Ros, J. D. (1989). The distribution pattern of benthic cnidarians in the Western Mediterranean. Scientia mar. 53: 19-35

Gili, J. M., Ros, J. D. (1985), Estudio cuantitativo de tres poblaciones circalitorales de cnidarios benticos. (A quantitative study of three circalittoral populations of benthic cnidarians). Investigación pesq. 49:323-352

Grigg, R. W. (1977). Population dynamics of two gorgonian corals. Ecology 58: 278-290

Hall, D. J., Cooper, W. E., Werner, E. E. (1970). An experimental approach to the production dynamics and structure of freshwater animal communities. Limnol. Oceanogr. 15: $838-928$

Horton, R. E. (1945). Erosional development of streams and their drainage basin, hydrophysical approach to quantitative morphology. Geol. Soc. Am. Bull. 56: 275-370

Johannes, R. E., Coles, S. L., Kuenzel, N. T. (1970). The role of zooplankton in the nutrition of some scleractinian corals. Limnol. Oceanogr. 15: 579-586

Jørgensen, S. E., Fris, M. B., Henriksen, J., Jørgensen, L. A., 
Mejer, H. F. (eds.) (1979). Handbook of environmental data and ecological parameters. In: Biswas, A. K., Biswas, M. R. (eds.) Environmental sciences and applications, Vol. 6. Pergamon Press, Oxford

Kinzie, R. A. (1970). The ecology of the gorgonians (Cnidaria, Octocorallia) of Discovery Bay, Jamaica. Ph.D. thesis, Yale University, New Haven, CT

Kinzie, R. A. (1973). The zonation of West Indian gorgonians. Bull. mar. Sci. 23: 93-155

LaBarbera, M. (1984). Feeding currents and particle capture mechanisms in suspension feeding animals. Am. Zool. 24 $71-84$

Lasker, H. R. (1979). Light-dependent activity patterns among reef corals: Montastrea cavernosa. Biol. Bull. 156: 196-211

Lasker, H. R. (1981a). A comparison of the particulate feeding abilities of three species of gorgonian soft coral. Mar. Ecol. Prog. Ser. 5: 61-67

Lasker, H. R. (1981b). Phenotypic variation in the coral Montastrea cavernosa and its effects on colony energetics. Biol. Bull. 160: 292-302

Lasker, H. R., Gottfried, M. D., Coffroth, M. A. (1983). Effects of depth on the feeding capabilities of two octocorals. Mar. Biol. 73: 73-78

Leversee, G. J. (1976). Flow and feeding in fan-shaped colonies of the gorgonian coral, Leptogorgia. Biol. Bull. 151: $344-356$

Mariscal, R. N., Bigger, C. H. (1977). Possible ecological significance of octocoral epithelial ultrastructure. Proc. 3rd int. coral Reef Symp. 1: 127-134

McFadden, C. S. (1986). Colony fission increases particle capture rates of a soft coral: advantages of being a small colony. J. exp. mar. Biol. Ecol. 103: 1-20

Mitchell, N. D., Dardeau, M. R., Schroeder, W. W. (1993). Colony morphology, age structure, and relative growth of two gorgonian corals, Leptogorgia hebes (Verrill) and Leptogorgia virgulata (Lamarck) from the northern Gulf of Mexico. Coral Reefs 12: 65--70

Murdock, G. R. (1978). Digestion, assimilation, and transport of food in the gastrovascular cavity of a gorgonian octocoral (Cnidaria; Anthozoa). Bull. mar. Sci. 28: 354-362

Murphy, G. F. (1971). Note clarifying a production model. Limnol. Oceanogr 16: 981-983

Muscatine, L., Porter, J. W. $(1977)$. Reef corals: mutualistic symbiosis adapted to nutrient-poor environments. BioSci. 27: $454-460$

Muzik, K. (1982). Octocorallia (Cnidaria) from Carrie Bow Cay, Belize. In: Rutzler, K., Macintyre, I. G. (eds.) The Atlantic barrier reef system at Carrie Bow Cay, Belize I. Structure and communities. Smithson. Contrib mar. Sci. 12: $309-316$

Okamura, B. (1985). The effects of ambient flow velocity, colony size, and upstream colonies on the feeding success of bryozoa. II. Conopeum reticulum (Linnaeus), an encrusting species. J. exp. mar. Biol. Ecol. 89: 69-80

Opresko, D. M. (1973). Abundance and distribution of shallow-water gorgonians in the area of Miami, Florida. Bull. mar. Sci. 23: 535-558

Pascual, J., Flos, J. (1984). Meteorologia i oceanografia. In: Ros, J. D., Olivella, I., Gili, J. M. (eds.) Els sistemes naturais de les illes Medes. Arxius Sec. Ciènc. Institut d'Estudis catalans, Barcelona 73: 75-114

Patterson, M. R. (1984). Patterns of whole colony prey capture in the octocoral, Alcyonium siderium. Biol. Bull. 167: $613-629$

Patterson, M. R. (1991). Passive suspension feeding by an octocoral in plankton patches: empirical test of a mathematical model. Biol. Bull. 180: 81-92
Pearre, S. (1982). Estimating prey preference by predators: uses of various indices, and a proposal of another based on $\chi^{2}$ Can. J. Fish. Aquat. Sci. 39: 914-923

Porter, J. W. (1974). Zooplankton feeding by the Caribbean reef-building coral Montastrea cavernosa. Proc. 2nd int. coral Reef Symp. 1. 111-125

Purcell, J. E. (1977). The diet of large and small individuals of the sea anemone Metridium senila. Bull. South Calif. Acad. Sci. 76: 168-172

Purcell, J. E. (1992). Effects of predation by the scyphomedusan Chrysaora quinquecirrha on zooplankton populations in Chesapeake Bay, USA. Mar. Ecol. Prog. Ser. 87 : $65-76$

Reeve, M. R., Walter, M. A. (1978). Nutritional ecology of ctenophores. A review of recent research. Adv. mar Biol. 15: $249-287$

Riedl, R. (1966). Biologie der Meereshöhlen. Paul Parey, Berlin

Robbins, R. E., Shick, J M. (1980). Expansion-contraction behavior in the sea anemone Metridium senile: enviromental cues and energetic consequences. In: Schith, D. C. Tiffon, V. (eds.) Nutrition in the lower Metazoa. Pergamon Press, New York, p. 101-116

Roushdy, H. M., Hansen, V. K. (1961). Filtration of phytoplankton by the octocoral Alcyonium digitatum L. Nature 190: $649-650$

Russo, A. R. (1985). Ecological observations on the gorgonian sea fan Eunicella cavolinii in the Bay of Naples. Mar. Ecol. Prog. Ser. 24: 155-159

Sebens, K. P. (1977). Autotrophic and heterotrophic nutrition of coral reef zoanthids. Proc. 3rd int, coral Reef Symp. 1: $397-406$

Sebens, K. P. (1981). The allometry of feeding, energetics, and body size in three sea anemone species. Biol. Bull. 161: $152-171$

Sebens, K. P. (1987). Coelenterata. In: Pandian, T J., Vernberg, F. J. (eds.) Animal energetics. 1. Academic Press, San Diego, p. 55-120

Sebens, K. P., DeRiemer, K. (1977). Diel cycles of expansion and contraction in coral reef anthozoans. Mar. Biol. 43 $247-256$

Sebens, K. P., Koehl, M. A. R. (1984). Predation on zooplankton by the benthic anthozoans Alcyonium siderium (Alcyonacea) and Metridium senile (Actiniaria) in the New England subtidal. Mar. Biol. 81: 255-271

Sponaugle, S., LaBarbera, M. (1991). Drag-induced deformation: a functional feeding strategy in two species of gorgonians. J. exp. mar. Biol. Ecol. 148: 121-134

Strahler, A. N. (1952). Hypsometric (area-altitude) analysis of erosional topography. Geol. Soc. Am. Bull. 64: 165-176

True, M. A. (1970). Étude quantitative de quatre peuplements sciaphiles sur substrat rocheux dans la région marseillaise. Bull. Inst. Océanogr., Monaco 1410: 1-48

Weinberg, S. (1979). Autoecology of shallow-water Octocorallia from Mediterranean rocky substrata. I. The Banyuls area. Bijdr. Dierk. 49: 1-15

Weinberg, S. (1980). Autoecology of shallow-water Octocorallia from Mediterranean rocky substrata. II. Marseilles, Côte d'Azur and Corsica. Bijdr. Dierk. 50: 73-86

Weinberg, S. (1991). Faut-il protéger les gorgones de Méditerranée? In: Bouderque, M., Avon, C. F., Gravez, V. (eds.) Les espèces marines à protéger en Méditerranée. GIS Posidonie, Marseilles, p. 47-52

Wellington, G. M. (1982). An experimental analysis of the effects of light and zooplankton on coral zonation. Oecologia $52: 311-320$

Yonge, C. M., Nicholls, A. G. (1930). Studies on the physiol- 
ogy of corals. II. Digestive enzymes with notes on the speed of digestion. Scient. Rep. Grt Barrier Reef Exped. 1: $15-57$

Yonge, C. M., Nicholls, A. G. (1931). Studies on the physiology of corals. V. The effect of starvation in light and in darkness on the relationship between corals and zooxanthellae. Scient. Rep. Grt Barrier Reef Exped. 1: 177-211

Yoshioka, P. M., Yoshioka, B. B. (1989). Effects of wave

This article was presented by $R$. N. Hughes (Senior Editorial Advisor), Bangor, UK energy, topographic relief and sediment transport on the distribution of shallow-water gorgonians of Puerto Rico. Coral Reefs 8: 145-152

Zamer, W. E., Shick, J. M. (1987). Physiological energetics of the intertidal sea anemone Anthopleura elegantissima. II. Energy balance. Mar. Biol. 93: 481-491

Zar, J. H. (1984). Biostatistical analysis. Prentice-Hall, Englewood Cliffs, NJ

Manuscript first received: March 7, 1994

Revised version accepted: August 15, 1994 